\title{
The impact of panicle and shoot pruning on inflorescence and yield related developments in some mango cultivars
}

\author{
T. Yeshitela1, P.J. Robbertse ${ }^{2}$, P.J.C. Stassen ${ }^{3}$
}

${ }^{1}$ Alemaya University, Department of Plant Sciences, P.O.Box 165 Dire Dawa, Ethiopia. ${ }^{2}$ Department of Plant Production \& Soil Sciences, University of Pretoria, Pretoria 0002, South Africa. ${ }^{3}$ Department of Horticulture, University of Stellenbosch, Stellenbosch 7600, South Africa.

\begin{abstract}
The effect of different kinds of pruning treatments was studied on Keitt and Tommy Atkins cultivars over two seasons. The trial was conducted at Bavaria Estate, around Hoedspruit area, Northern province of South Africa (latitude: 24025'S; longitude: 30 54'E; elevation: $600 \mathrm{~m}$ ). With regard to inflorescence development, panicle pruning (during full bloom) at the point of apical bud attachment proved to induce re-flower, more rapid fruit development and more fruit per panicle than the other panicle pruning treatments. Renewal (early in the season when fruit were on the tree) as well as post harvest pruning (especially for early cultivars) treatments were also observed to effect a well-synchronized inflorescence development and adequate number of productive inflorescences per season. Post harvest pruning treatments produced a significantly higher result for the vegetative growth parameters in both cultivars while the control trees showed the lower result. Pertaining to yield, the trend showed that, promising increment could be expected after the second season (with vigilant management of the trees) especially from panicle pruning at apical bud attachment and shoot pruning treatments on 'Tommy Atkins'. 'Keitt' was found to be not responsive to the pruning treatments applied for various parameters observed.
\end{abstract}

Key words: Mango, panicle and shoot pruning, inflorescence development, yield

\section{Introduction}

The mango inflorescence is a much-branched terminal panicle with a few hundred to over 6000 flowers (Wolstenholme and Mullins, 1982). Number of flowers per inflorescence in mango varies depending on the cultivar, the cultural practices adopted and the climatic conditions experienced by the trees (Chadha and Pal, 1986). The mango is andromonoecious, which means that each inflorescence bears both hermaphrodite and staminate flowers (Coetzer et al., 1995). In mango, the removal of the apical bud or inflorescence on terminal shoots just prior to or during the flowering period results in the development of normally inhibited axillary buds adjacent to the point of cuttings (Reece $e t$ al., 1946). These buds usually develop as inflorescences, particularly if pruning is performed shortly before or after the start of normal bud development (Issarakraisila et al., 1991, Singh et al., 1974).

Clearly, relative light flowering can limit yield in most fruit and nut species (Stover, 1999). This commonly occurs before mature bearing commences and in 'off' years for varieties that displays alternate bearing. During mature bearing, many species will bear fruit numbers that exceed commercially desired levels, resulting in excessively small fruit and accentuating alternate bearing. Many farmers are still afraid to apply panicle pruning since they consider it to be a loss of the whole crop. Farmers are also reserved from pruning their trees since they consider it to be loss of vital vegetative parts. This report supplies information about the effects of different pruning types on various inflorescence and fruit development aspects that were applied on Keitt ('KT') and Tommy Atkins ('TA') cultivars over a period of two seasons.

\section{Materials and methods}

The varying types of pruning trials were conducted on 'KT' and 'TA' mango cultivars at Bavaria Estate in Hoedspruit area, Northern Province of South Africa (latitude: 2425'S; longitude: $30^{\circ} 54^{\prime} \mathrm{E}$; elevation: $600 \mathrm{~m}$ ). For both cultivars, sixty-three trees were randomly selected from an eight-year-old orchard. Nine trees were assigned for each treatment, where each of the treatment was replicated three times on three separate trees in each of the three blocks. Then, twenty randomly selected shoots per tree (five from each of the four wind directions) containing well developed terminal buds were tagged before applying the treatments to follow up the impact of the treatments on inflorescence development and fruit quality. The treatments were applied at three stages of bud development namely (i) when the buds on the tagged shoots were swelling and about to flush, (ii) when the advanced inflorescence were in full bloom, (iii) during some vegetative growth stages. The following seven treatments were applied in both cultivars and only the treatment numbers designated for each treatment below are used in the discussion.

(1) Inflorescence removal at the point of apical bud attachment during full bloom, (2) Inflorescence removal together with apical whorl of leaves subtending the inflorescence (about $5 \mathrm{~cm}$ deep from the tip) during full bloom, (3) $50 \%$ of the total inflorescences (every alternate shoot of the tagged branches) removed together with apical whorl of leaves subtending the inflorescence during full bloom, (4) Renewal pruning where $20-30 \%$ of terminal shoots with weak, misshaped and small fruit are cut back to a suitable node in October, (5) Postharvest pruning where terminal shoots that had been bearing fruit the previous season were cut back to 
a suitable node, (6) Terminal buds removed just before bud break, (7) No pruning treatments (control trees). The treatments were applied on the tagged shoots and these shoots were used to determine the following parameters: inflorescence development (by allocating numeric values as in Fig. 1) in different periods, percent terminal shoots with panicles during and after anthesis, extent of re-flowering expressed as percentage, fruit development and percent shoots fruiting. In order to apply the three-panicle pruning treatments (treatments one, two and three), only shoots bearing a single inflorescence per terminal branch were tagged. This was done to study the extent of re- flowering from the axillary buds at a later stage. Extent of re-flowering was determined only for panicle pruning treatments where the number of panicles developed per tagged shoots after inflorescence removal was recorded and compared with the single panicle per tagged shoot before inflorescence removal. Vegetative flush growth status of the trees was assessed at different periods (once the development of new vegetative flush had hardened off) depending on a specific treatment. The total number of new flushes developed, length of twenty randomly selected new flushes and length as well as width of forty newly developed leaves randomly selected from the whole tree canopy were measured. The leaf area of each of the forty leaves measured was calculated using the formula (Nii et al., 1995): $\mathrm{Y}=-0.146+0.706 \mathrm{x}\left[\mathrm{r}^{2}=0.995\right.$, where $\mathrm{Y}=$ leaf area $\left(\mathrm{cm}^{2}\right)$ and $\mathrm{x}=$ leaf length $(\mathrm{cm}) \mathrm{X}$ width $(\mathrm{cm})]$. The total average leaf area per tree was determined using the total number of new leaves developed per tree and the average leaf area from the sampled new leaves and expressed in $\mathrm{cm}^{2}$.

Quantitative parameters like fruit number and weight were recorded during harvesting. Yield was determined using total fruit weight per tree, which is finally expressed as tons ha ${ }^{-1}$. The fruit firmness was measured (after storing the fruit at a temperature of $10^{\circ} \mathrm{C}$ for 28 days to simulate shipping) using a penetrometer probe after peeling a portion of the exocarp and expressed as $\mathrm{kg}$ $\mathrm{cm}^{-2}$. Some quality parameters were also analysed to see whether the treatments produced any effect. Two representative fruit from different size groups were taken for analyzing quality parameters after shipping simulation (storing the fruit in a cold store for 28 days at $10^{\circ} \mathrm{C}$ ). The total soluble solids (TSS) in the sample fruit pulp was measured using Euromex refractometer and expressed as $\%$ Brix.

The pulp of the sampled fruit was also used to determine the titratable acid ( $\mathrm{Ta}$ ) after stirring the pulp with a juice Blender and centrifuging the same for ten minutes at 1000-rpm. A Mettler Toledo DL 25 titrator was used to determine the titratable acids,

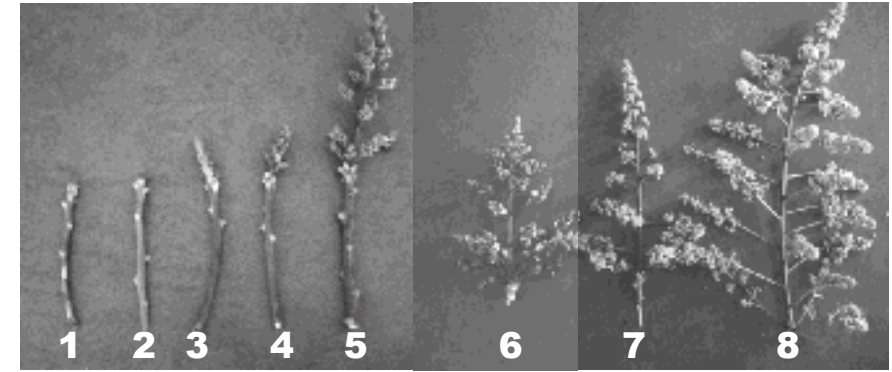

Fig. 1. Stages of inflorescence development (SID) in mango and it is expressed in $\mathrm{m}$ eq. $\mathrm{L}^{-1}$.

All treatment trees were subjected to the standard orchard management practises as applied at the Fruit Estate and a randomised complete block design was used with three blocks and three trees per block for each treatment. The collected data was analysed using the statistical program GenStat (2000) and treatment means were separated using Fishers' protected t-test least significant difference (LSD) at the $5 \%$ level of significance (Snedecor and Cochran, 1980).

\section{Result and discussion}

Data for the inflorescence as well as vegetative development is presented only for the 2002-2003 season.

\section{Effect of treatments on inflorescence development}

Stages of inflorescence development before treatment application: During data gathering, numbers (1-8) were assigned to describe the different stages of inflorescence development (Fig. 1) where stage 1 is around 'pre-shoot stage' (about to enter rapid phase of primary axis elongation) and stage 8 represent a fruiting panicle and approaching bare panicle stage (Oosthuyse \& Jacobs, 1996). In 2002-2003 season, variation among shoots of the treatment trees at the time of tagging were between numeric values of one up to three in the case of 'TA' and four to five for 'KT' indicating similar developmental stages just before treatment application (Tables 1a, 2a and Fig. 1). This verifies that the results obtained afterwards were purely due to treatment effects.

Inflorescence and fruit related developments on September, October and November 2002: One month after treatment application (September, 2002), lateral buds on decapitated branches of treatment one in both cultivars started producing lateral inflorescences (Tables 1a and 2a). During the same period, however, not even a single shoot of trees from treatment two had produced an inflorescence or showed any form of bud

Table 1a. Flower and fruit related developments in 'Tommy Atkins' during September

\begin{tabular}{lcccccc}
\hline $\begin{array}{l}\text { Pruning } \\
\text { treatments }\end{array}$ & SID & $\begin{array}{c}\text { NID in } \\
\text { September }\end{array}$ & $\begin{array}{c}\text { PTSP in } \\
\text { September }\end{array}$ & $\begin{array}{c}\text { ERF in } \\
\text { September }\end{array}$ & $\begin{array}{c}\text { FD in } \\
\text { September }\end{array}$ & $\begin{array}{c}\text { PSF in } \\
\text { September }\end{array}$ \\
\hline 1 & $2.00 \mathrm{a}$ & $0.68 \mathrm{c}$ & $0.46 \mathrm{c}$ & $0.68 \mathrm{a}$ & $0.95 \mathrm{c}$ & $0.43 \mathrm{c}$ \\
2 & $1.75 \mathrm{a}$ & $0.00 \mathrm{~d}$ & $0.00 \mathrm{~d}$ & $0.00 \mathrm{~b}$ & $0.00 \mathrm{~d}$ & $0.00 \mathrm{~d}$ \\
3 & $2.00 \mathrm{a}$ & $0.65 \mathrm{c}$ & $0.53 \mathrm{c}$ & $0.65 \mathrm{a}$ & $0.96 \mathrm{c}$ & $0.47 \mathrm{c}$ \\
4 & $2.04 \mathrm{a}$ & $1.38 \mathrm{a}$ & $0.93 \mathrm{ab}$ & - & $1.95 \mathrm{a}$ & $0.90 \mathrm{a}$ \\
5 & $1.82 \mathrm{a}$ & $1.24 \mathrm{ab}$ & $0.85 \mathrm{~b}$ & - & $1.56 \mathrm{~b}$ & $0.75 \mathrm{~b}$ \\
6 & $1.68 \mathrm{a}$ & $0.00 \mathrm{~d}$ & $0.00 \mathrm{~d}$ & $0.00 \mathrm{~b}$ & $0.00 \mathrm{~d}$ & $0.00 \mathrm{~d}$ \\
7 & $1.78 \mathrm{a}$ & $1.14 \mathrm{~b}$ & $0.94 \mathrm{a}$ & - & $1.96 \mathrm{a}$ & $0.93 \mathrm{a}$ \\
$\operatorname{LSD}(p=0.05)$ & $\mathrm{NS}$ & $0.157^{* *}$ & $0.082^{* *}$ & $0.054^{* *}$ & $0.281^{* *}$ & $0.133^{* *}$ \\
\hline
\end{tabular}

${ }^{*}$ Significant at $p=0.01$, NS=non significant; Means within columns followed by the same letter did not differ significantly at $5 \%$ level 
Impact of panıcle and shoot prunıng on intlorescence and yield related developments in mango

Table 1b. Fflower and fruit related developments in 'Tommy Atkins' during October and November

\begin{tabular}{lccccccc}
\hline $\begin{array}{l}\text { Pruning } \\
\text { treatments }\end{array}$ & $\begin{array}{c}\text { NID in } \\
\text { October }\end{array}$ & $\begin{array}{c}\text { PTSP in } \\
\text { October }\end{array}$ & $\begin{array}{c}\text { ERF in } \\
\text { October }\end{array}$ & $\begin{array}{c}\text { FD in } \\
\text { October }\end{array}$ & $\begin{array}{c}\text { PSF in } \\
\text { October }\end{array}$ & $\begin{array}{c}\text { FD in } \\
\text { November }\end{array}$ & $\begin{array}{c}\text { PSF in } \\
\text { November }\end{array}$ \\
\hline 1 & $1.11 \mathrm{a}$ & $0.78 \mathrm{a}$ & $1.11 \mathrm{a}$ & $1.56 \mathrm{a}$ & $0.57 \mathrm{a}$ & $2.10 \mathrm{a}$ & $0.81 \mathrm{a}$ \\
2 & $0.32 \mathrm{c}$ & $0.32 \mathrm{c}$ & $0.32 \mathrm{c}$ & $0.41 \mathrm{~d}$ & $0.10 \mathrm{c}$ & $0.47 \mathrm{~d}$ & $0.21 \mathrm{c}$ \\
3 & $0.78 \mathrm{~b}$ & $0.65 \mathrm{~b}$ & $0.78 \mathrm{~b}$ & $1.24 \mathrm{~b}$ & $0.51 \mathrm{a}$ & $1.29 \mathrm{~b}$ & $0.54 \mathrm{~b}$ \\
4 & - & - & - & - & - & - & - \\
5 & - & - & - & - & - & - & - \\
6 & $0.89 \mathrm{~b}$ & $0.74 \mathrm{a}$ & $0.89 \mathrm{~b}$ & $0.99 \mathrm{c}$ & $0.25 \mathrm{~b}$ & $1.10 \mathrm{c}$ & $0.47 \mathrm{~b}$ \\
7 & - & - & - & - & - & - & - \\
$\mathrm{LSD}(p=0.01)$ & $0.205^{* *}$ & $0.065^{* *}$ & $0.160^{* *}$ & $0.187^{* *}$ & $0.132^{* *}$ & $0.093^{* *}$ & $0.194^{* *}$ \\
\hline
\end{tabular}

${ }^{*}$ Significant at $p=0.01$; Means within columns followed by the same letter did not differ significantly at $5 \%$ level

development. This is something related to induction. The more terminal and further developed axillary buds were more receptive for the induction and had therefore already been induced to form inflorescences (like in the case of treatment one) in contrary to the less developed axillary buds (treatment two).

When the apical bud was removed, the inhibited but induced axillary buds were released and started developing lateral inflorescences similar to the observations of Reece et al. (1946). These buds usually develop as inflorescences, particularly if pruning is performed shortly before or after the start of normal terminal bud development (Issarakraisila et al., 1991, Singh et al., 1974). Oosthuyse and Jacobs (1996) also found a higher rate of re-flowering in 'Sensation' when the inflorescence was removed at the site of apical bud or inflorescence attachment as compared to when pruning included the leaves clustered around the shoot apex. They explained this to be due to the presence of intercalation (clustering of axillary buds at the shoot apex) giving rise to an increase in the number of axillary buds developing in response to pruning. In treatment three, none of the lateral buds from the $50 \%$ decapitated branches produced lateral inflorescences or vegetative growth during the September 2002. The same was true for treatment six in 'TA' trees. The undisturbed inflorescences from the other treatments remained intact until the September 2002 observation. For the determination of extent of re-flowering, only treatments one, two, three and six were applicable. Reflowering wasn't determined for treatments four, five as well as the control trees since the inflorescences were not pruned. The highest re-flowering percentage was recorded for treatment six in case of 'KT' (Table 2a) and treatment one in the case of 'TA' (Table 1a), which was not significantly different to treatment three. Treatment two had a zero re-flowering percentage in both cultivars and an addition of treatment six in 'TA' (Tables 1a and 2a). It was observed that some of the lateral buds of treatment one on 'TA' trees had given rise to inflorescence (re-flower) and some of these inflorescences produced golf-sized fruit (with an approximate fruit diameter of $3 \mathrm{~cm}$ ) (Table 1a). This gives an indication that inflorescences from lateral buds mature and bore fruit relatively earlier than those from apical buds on this cultivar. On the other hand, even if inflorescence development was faster on 'KT' trees, fruit development didn't proceed with the same pace. There was no sign of fruiting for treatment two for both cultivars since there was no inflorescence development. Treatment three produced a lot of inflorescences and also different stages of fruit development from the unpruned shoots again on both cultivars. The inflorescences of most of the other treatments that didn't involve inflorescences pruning treatments have shown good fruit development, which in most case was marble size fruit stage (with an approximate fruit diameter of $1 \mathrm{~cm}$ ) in both cultivars. Like in the case of inflorescence development, fruit setting stages in treatments four and five were delayed than the control trees.

Another observation was made two months after treatment application during October and the same parameters as in the case of September observations were studied. Since there was a clear developmental variability among the inflorescence/bud removal (treatments one, two, three and six), shoot pruning (treatments four and five) treatments as well as the control trees, only the inflorescence/bud removal treatments were compared among each other. A significantly higher value of all the parameters was observed for treatment six in 'KT' (Table 2b) and for treatment one in the case of 'TA' (Table 1b). The majority of the shoots from treatment six (specially on ' $\mathrm{KT}$ ' trees) had shown development of healthy inflorescences in which some of them already started fruiting. Most of the buds that were bursting during September observation of treatment six, that were exposed to sufficient cold spells during the winter, proved to be inflorescences in the October observation. Nunez-Elisea and Davenport (1995) indicated that growth of induced buds in the presence of cool temperature was found to be essential for floral initiation. Generally, it is clear from the October observation that, either inflorescence or bud pruning treatments didn't cause a failure of re-flowering and fruiting except that there was a delay. The effect of a favourable climatic condition during this period was an important factor that contributed for this result.

Fruiting of the treatment trees was also observed during November. Again, the inflorescence/bud removal treatments (treatments one, two, three and six) were compared among each other. There was a significantly higher value for fruit development and percent shoots fruiting in treatment one specially in ' $\mathrm{TA}$ ' and together with treatment six in 'KT' (Tables $1 \mathrm{~b}$ and $2 \mathrm{~b}$ ). Significant amount of the fruit produced by treatment one were above golf size especially on 'TA' trees. On the other hand, the inflorescences on the tagged shoots of trees from treatment six were having the majority of their fruit in between marble and golf size; still few of them being bigger sized fruit on 'TA' (Table 1b) and more significantly in 'KT' trees (Table 2b). Generally, it was observed that even if inflorescence development was earlier on 'KT' than 'TA' trees, the process of fruit development became very slow to end up with an early fruit development and maturation on 'TA'. The inflorescences on 'KT' trees continued to hungabout in their fruit development process, and consequently matured late.

Effect of treatments on vegetative growth: Regarding ' $\mathrm{KT}$ ', trees 
Table 2a. Flower and fruit related developments in 'Keitt' during September

\begin{tabular}{lcccccc}
\hline $\begin{array}{l}\text { Pruning } \\
\text { treatments }\end{array}$ & SID & $\begin{array}{c}\text { NID in } \\
\text { September }\end{array}$ & $\begin{array}{c}\text { PTSP in } \\
\text { September }\end{array}$ & $\begin{array}{c}\text { ERF in } \\
\text { September }\end{array}$ & $\begin{array}{c}\text { FD in } \\
\text { September }\end{array}$ & $\begin{array}{c}\text { PSF in } \\
\text { September }\end{array}$ \\
\hline 1 & $4.69 \mathrm{a}$ & $0.56 \mathrm{c}$ & $0.29 \mathrm{~b}$ & $0.56 \mathrm{a}$ & $0.43 \mathrm{bc}$ & $0.14 \mathrm{~cd}$ \\
2 & $4.79 \mathrm{a}$ & $0.00 \mathrm{~d}$ & $0.00 \mathrm{c}$ & $0.00 \mathrm{~b}$ & $0.00 \mathrm{c}$ & $0.00 \mathrm{~d}$ \\
3 & $4.46 \mathrm{a}$ & $0.63 \mathrm{c}$ & $0.35 \mathrm{~b}$ & $0.63 \mathrm{a}$ & $0.56 \mathrm{~b}$ & $0.22 \mathrm{bc}$ \\
4 & $4.38 \mathrm{a}$ & $1.35 \mathrm{ab}$ & $0.50 \mathrm{~b}$ & - & $0.86 \mathrm{ab}$ & $0.36 \mathrm{abc}$ \\
5 & $4.62 \mathrm{a}$ & $1.13 \mathrm{~b}$ & $0.53 \mathrm{~b}$ & - & $0.99 \mathrm{ab}$ & $0.46 \mathrm{ab}$ \\
6 & $4.78 \mathrm{a}$ & $1.07 \mathrm{c}$ & $0.39 \mathrm{~b}$ & $1.07 \mathrm{a}$ & $0.68 \mathrm{~b}$ & $0.29 \mathrm{bc}$ \\
7 & $4.68 \mathrm{a}$ & $1.74 \mathrm{a}$ & $0.75 \mathrm{a}$ & - & $1.38 \mathrm{a}$ & $0.63 \mathrm{a}$ \\
LSD & $\mathrm{NS}$ & $0.520^{* *}$ & $0.243^{* *}$ & $0.541^{*}$ & $0.430^{* *}$ & $0.28^{* *}$ \\
\hline
\end{tabular}

Table 2b. Flower and fruit related developments in 'Keitt' during October and November

\begin{tabular}{lccccccc}
\hline $\begin{array}{l}\text { Pruning } \\
\text { treatments }\end{array}$ & $\begin{array}{c}\text { NID on } \\
\text { October }\end{array}$ & $\begin{array}{c}\text { PTSP on } \\
\text { October }\end{array}$ & $\begin{array}{c}\text { ERF on } \\
\text { October }\end{array}$ & $\begin{array}{c}\text { FD on } \\
\text { October }\end{array}$ & $\begin{array}{c}\text { PSF on October } \\
\text { October }\end{array}$ & $\begin{array}{c}\text { FD on } \\
\text { November }\end{array}$ & $\begin{array}{c}\text { PSF on } \\
\text { November }\end{array}$ \\
\hline 1 & $1.17 \mathrm{ab}$ & $0.72 \mathrm{a}$ & $1.17 \mathrm{~b}$ & $1.43 \mathrm{a}$ & $0.50 \mathrm{a}$ & $2.07 \mathrm{a}$ & $0.69 \mathrm{a}$ \\
2 & $0.44 \mathrm{c}$ & $0.38 \mathrm{c}$ & $0.44 \mathrm{c}$ & $0.58 \mathrm{c}$ & $0.22 \mathrm{c}$ & $1.50 \mathrm{c}$ & $0.43 \mathrm{c}$ \\
3 & $0.82 \mathrm{~b}$ & $0.53 \mathrm{~b}$ & $0.82 \mathrm{~b}$ & $1.01 \mathrm{~b}$ & $0.33 \mathrm{~b}$ & $1.60 \mathrm{~b}$ & $0.54 \mathrm{~b}$ \\
4 & - & - & - & - & - & - & - \\
5 & - & - & - & - & - & - & - \\
6 & $1.58 \mathrm{a}$ & $0.72 \mathrm{a}$ & $1.58 \mathrm{a}$ & $1.47 \mathrm{a}$ & $0.53 \mathrm{a}$ & $2.13 \mathrm{a}$ & $0.74 \mathrm{a}$ \\
7 & - & - & - & - & - & - & - \\
$\mathrm{LSD}$ & $0.362^{* *}$ & $0.094^{* *}$ & $0.369^{* *}$ & $0.387^{* *}$ & $0.088^{* *}$ & $0.074^{* *}$ & $0.095^{* *}$ \\
\hline
\end{tabular}

** Significant at $p=0.01, \mathrm{NS}=$ non significant

Means within columns followed by the same letter did not differ significantly at $5 \%$ level

Keys: SID: Stages of Inflorescence Development, PTSP: Percent Tagged Shoots with Panicles, FD: Fruit Development

ERF: Extent of Re-flowering percentage, NID: Number of Inflorescence Developed, PSF: Percent Tagged Shoots Fruiting

from treatment five produced the longest flush and the shortest was observed for trees of treatment two. In 'TA' the same result like that of 'KT' was obtained for this parameter but the length of new flushes of treatment five was not significantly different to that of treatment four. The shortest flushes were observed from the control trees in 'TA'. The highest number of new flushes development for ' $\mathrm{KT}$ ' and 'TA' was seen from treatments four and five and lowest for trees from treatment three. The number of leaves developed per new flush was found to be directly proportional to the length of new flushes with a positive correlation of $(\mathrm{r}=0.713, p=0.071)$ for ' $\mathrm{TA}$ ' and $(\mathrm{r}=0.720, p=0.067)$ for ' $\mathrm{KT}$ '. Consequently, the same trend as that of length of new flushes was observed, viz., the highest number of new leaves

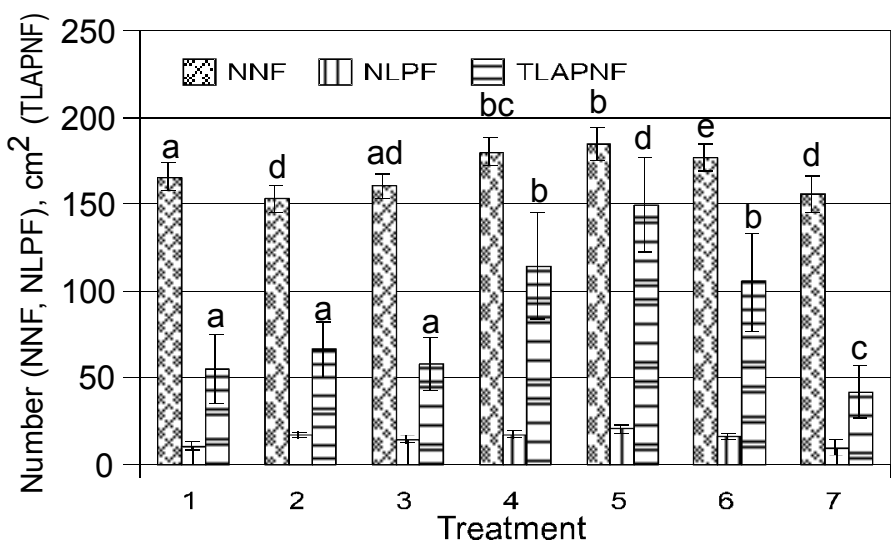

Fig. 2. Effect of pruning treatments on number of new flushes (NNF), number of leaves per flushes (NLPF) and total leaf area per new flushes (TLAPNF- for convenience values written at $10^{-4}$ ) of 'Tommy Atkins' was observed for both treatments four and five in the case of 'KT' but significantly higher value was observed for only treatment five in 'TA'. The lowest value was for the control trees in the case of 'TA'. The direct relationship between flush length and leaf number also implies a direct relationship between flush length and number of axillary buds per flush, thus increasing the scope for subsequent pruning. The result for leaf area of the forty newly developed leaves showed that treatments four and five produced the best result on 'TA' and ' $\mathrm{KT}$ '. In both cultivars, trees from treatment two showed the lowest result. A significantly higher total leaf area per new flush in both cultivars was observed for treatment five (Fig. 2 and 3). In general, the control trees as well as treatment two showed poor vegetative growth. In the case of the control trees, the trees were not encouraged to

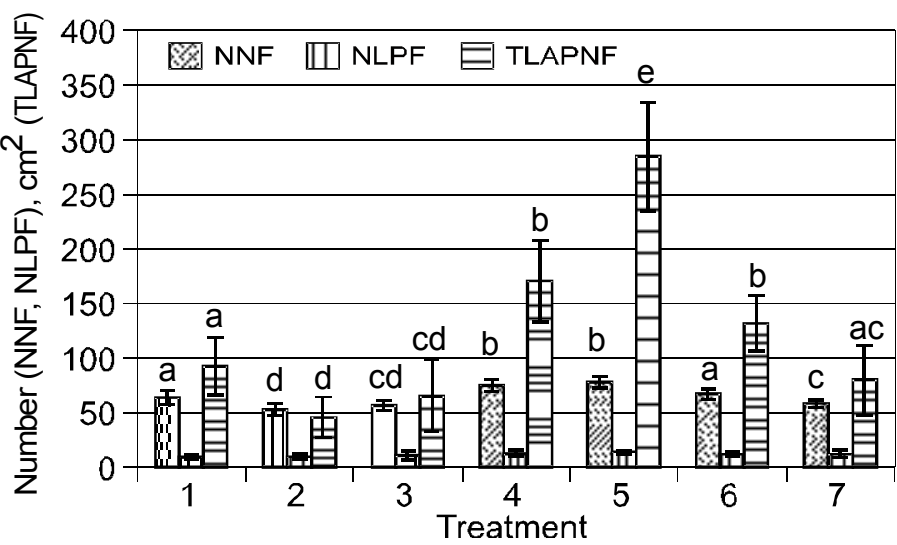

Fig. 3. Effect of pruning treatments on number of new flushes (NNF), number of leaves per flushes (NLPF) and total leaf area per new flushes (TLAPNF- for convenience values written at $10^{-4}$ ) of 'Keitt' 
Impact of panicle and shoot pruning on intlorescence and yield related developments in mango

Table 3. Yield data of 'Tommy Atkins' over two seasons

\begin{tabular}{|c|c|c|c|c|c|c|}
\hline \multirow{2}{*}{$\begin{array}{l}\text { Pruning } \\
\text { Treatments }\end{array}$} & \multicolumn{2}{|c|}{ Total number of fruits } & \multicolumn{2}{|c|}{ Yield (ton ha-1) } & \multicolumn{2}{|c|}{ Average fruit mass (g) } \\
\hline & 2001 & 2002 & 2001 & 2002 & 2001 & 2002 \\
\hline$\overline{1}$ & $58.7 a$ & $71.1 \mathrm{a}$ & $21.85 a$ & $26.79 a$ & $0.39 a$ & $0.48 a$ \\
\hline 2 & $65.3 a$ & $55.0 \mathrm{e}$ & $23.57 a$ & $20.31 \mathrm{c}$ & $0.42 a$ & $0.36 \mathrm{~d}$ \\
\hline 3 & $62.3 a$ & 58.8de & $22.37 a$ & $21.69 c$ & $0.40 \mathrm{a}$ & $0.39 \mathrm{~cd}$ \\
\hline 4 & $64.2 \mathrm{a}$ & $66.8 \mathrm{abc}$ & $23.13 a$ & 25.17ab & $0.41 \mathrm{a}$ & $0.45 a b$ \\
\hline 5 & $64.0 \mathrm{a}$ & $68.1 \mathrm{ab}$ & $22.47 a$ & $25.54 a$ & $0.40 \mathrm{a}$ & $0.46 \mathrm{a}$ \\
\hline 6 & $60.6 a$ & $64.3 \mathrm{bcd}$ & $21.94 a$ & $24.96 \mathrm{ab}$ & $0.39 a$ & $0.45 a b$ \\
\hline 7 & $63.0 \mathrm{a}$ & $61.6 \mathrm{~cd}$ & $22.51 \mathrm{a}$ & $22.60 \mathrm{bc}$ & $0.40 \mathrm{a}$ & $0.40 c$ \\
\hline LSD & NS & $6.510^{\star *}$ & NS & $2.730^{\star *}$ & NS & $0.035^{\star \star}$ \\
\hline
\end{tabular}

${ }^{*}$ Significant at $p=0.01$

Means within columns followed by the same letter did not differ significantly at $5 \%$ level

Table 4. Yield data of 'Keitt' over two seasons

\begin{tabular}{|c|c|c|c|c|c|c|}
\hline \multirow{2}{*}{$\begin{array}{l}\text { Pruning } \\
\text { Treatments }\end{array}$} & \multicolumn{2}{|c|}{ Total number of fruits } & \multicolumn{2}{|c|}{ Yield (ton ha-1) } & \multicolumn{2}{|c|}{ Average fruit mass (g) } \\
\hline & 2001 & 2002 & 2001 & 2002 & 2001 & 2002 \\
\hline$\overline{1}$ & $45.7 a$ & $50.4 a$ & $17.20 \mathrm{a}$ & $18.53 a$ & $0.54 a$ & $0.53 a$ \\
\hline 2 & $33.3 a$ & $35.4 a$ & $12.90 \mathrm{a}$ & $14.99 \mathrm{a}$ & $0.59 a$ & $0.61 a$ \\
\hline 3 & $43.0 \mathrm{a}$ & $51.4 a$ & $15.20 \mathrm{a}$ & $18.42 a$ & $0.50 \mathrm{a}$ & $0.54 a$ \\
\hline 4 & $40.7 a$ & $42.2 a$ & $17.40 \mathrm{a}$ & $18.15 a$ & $0.61 a$ & $0.60 a$ \\
\hline 5 & $43.7 a$ & $39.7 a$ & $17.63 a$ & $18.10 \mathrm{a}$ & $0.59 a$ & $0.63 a$ \\
\hline 6 & $40.7 a$ & $35.4 a$ & $14.20 \mathrm{a}$ & $14.84 a$ & $0.51 a$ & $0.58 \mathrm{a}$ \\
\hline 7 & $36.7 a$ & $35.2 a$ & $14.20 \mathrm{a}$ & $14.06 a$ & $0.59 a$ & $0.57 \mathrm{a}$ \\
\hline LSD & NS & NS & NS & NS & NS & NS \\
\hline
\end{tabular}

Means within columns followed by the same letter did not differ significantly at $5 \%$ level

stimulate new shoot development with pruning and the old flower stalks that remained on the shoots inhibited sufficient vegetative growth. Limited new shoot development and flowering on these shoots, therefore, was due to sprouting of apical buds or just random development from previous harvest and inflorescence development wounds that activated axillary buds. The total leaf area of the newly developed shoots (together with the existing foliage of the tree) will determine the amount of carbohydrate to be produced, which shall be used for reserve demanding processes (flowering and fruiting) and if there would be any surplus, it replenish the reserve of the tree. For the crucial tree development processes, immediate post harvest pruning proved to produce better results for all the vegetative parameters observed. That was because pruning trees immediately after harvest encouraged the trees to produce enough new vegetative growth that can mature early in the season especially for an early cultivar. Like what is observed in this study for an early cultivar, it has been generally recognized that the ideal time to apply terminal shoot pruning is directly after harvest (Mullins, 1986, Oosthuyse, 1993, Ram, 1993). The rationale for their inference, is the allowance of maximum time for canopy recovery, shoot maturation and quiescence to maximize the likelihood of flowering of the new shoots arising after pruning. The need for quiescence might be linked to the reduction of endogenous gibberellins (Chen, 1987) and accumulation of starch reserves (Suryanarayana, 1987). Consequently, pruning by hastening post harvest flushing to occur uniformly, may effect earlier and more complete reserve replenishment (Oosthuyse, 1994, Davie et al, 1995). It was noted that flushing is important because new mango leaves are efficient producers of carbohydrates, the tree's building materials (Oosthuyse, 1995). On the other side, practicing post harvest pruning on late cultivars like ' $\mathrm{KT}$ ' may have a negative effect (especially with a very late harvest) on early development and maturation of vegetative growth that can bear the season's crop. This phenomenon may lead to the occurrence of biennial bearing. Renewal pruning, consequently, was primarily developed for late cultivars where $30 \%$ of the shoots were pruned when the fruit is still on the tree. Stassen et al. (1999) elaborated the applicability of renewal pruning for late cultivars.

Fruit weight and number: Generally, panicle pruning treatments (especially treatment two) showed a better result in 'TA' with regard to average fruit weight in 2001-2002 season even if not significant from the other treatments. The highest fruit mass was recorded for treatment one in 202-2003 season. The total number of fruit harvested per tree in 'TA' showed no significant difference among the treatments in 2001-2002 season. During 2002-2003 season, however, trees from treatment two produced the lowest number of fruit per tree, which was not significantly different from treatment three (Table 3) while the highest fruit number was recorded on trees where treatments one and five were applied, which was not significantly different from treatment four. Subsequently, it can be understood from the study that, even if pruning treatments involve removal of vegetative plant parts (especially renewal and post harvest pruning), not all pruning treatments have negatively affected the total number of fruit harvested or the average fruit weight more especially after the second season. Stassen et al. (1999) observed increase in fruit weight due to pruning on 'Sensation' mango. Regarding 'KT', however, there was no statistically significant difference among the treatments for the total number of fruit or average fruit weight per tree in both seasons (Table 4). 
Table 5. Fruit quality data of 'Tommy Atkins' over two seasons

\begin{tabular}{|c|c|c|c|c|c|c|}
\hline \multirow{2}{*}{$\begin{array}{l}\text { Pruning } \\
\text { Treatments }\end{array}$} & \multicolumn{2}{|c|}{ TSS (\% Brix) } & \multicolumn{2}{|c|}{ Titratable acids (m eq/l) } & \multicolumn{2}{|c|}{ Firmness $\left(\mathrm{kg} / \mathrm{cm}^{2}\right)$} \\
\hline & 2001 & 2002 & 2001 & 2002 & 2001 & 2002 \\
\hline$\overline{1}$ & $14.0 \mathrm{c}$ & $14.5 \mathrm{~cd}$ & $78.27 a$ & $78.24 a$ & $1.75 \mathrm{c}$ & $\overline{1.71 d}$ \\
\hline 2 & $13.8 \mathrm{c}$ & $14.1 d$ & $91.58 a$ & $97.20 \mathrm{a}$ & $2.10 a b$ & $2.13 a b$ \\
\hline 3 & $14.0 \mathrm{c}$ & $14.4 \mathrm{~cd}$ & $80.73 a$ & $80.13 a$ & $2.12 a b$ & $1.97 \mathrm{c}$ \\
\hline 4 & $15.1 \mathrm{a}$ & $15.3 a b$ & $81.00 \mathrm{a}$ & $80.82 a$ & $2.32 \mathrm{a}$ & $2.19 a$ \\
\hline 5 & $14.9 a$ & $15.6 a$ & $76.76 a$ & $75.51 a$ & $2.03 \mathrm{~b}$ & $1.91 \mathrm{c}$ \\
\hline 6 & $14.4 b$ & $14.8 \mathrm{bc}$ & $72.18 a$ & $69.33 a$ & 2.16ab & $1.93 \mathrm{c}$ \\
\hline 7 & $13.9 \mathrm{c}$ & 14.0d & $85.60 a$ & $84.48 a$ & $2.12 a b$ & $2.01 \mathrm{bc}$ \\
\hline LSD & $0.321^{* *}$ & $0.630^{* *}$ & NS & NS & $0.247^{* *}$ & $0.147^{* *}$ \\
\hline
\end{tabular}

** Significant at $p=0.01, \mathrm{NS}=$ non significant

Table 6. Fruit qualitaty of 'Keitt' over two seasons

\begin{tabular}{|c|c|c|c|c|c|c|}
\hline \multirow{2}{*}{$\begin{array}{l}\text { Pruning } \\
\text { Treatments }\end{array}$} & \multicolumn{2}{|c|}{ TSS (\% Brix) } & \multicolumn{2}{|c|}{ Titratable acids (m eq/l) } & \multicolumn{2}{|c|}{ Firmness $\left(\mathrm{kg} / \mathrm{cm}^{2}\right)$} \\
\hline & 2001 & 2002 & 2001 & 2002 & 2001 & 2002 \\
\hline 1 & $15.28 \mathrm{a}$ & $15.11 a$ & $12.87 a$ & $12.36 a$ & $1.33 a$ & $1.61 \mathrm{~b}$ \\
\hline 2 & $15.40 \mathrm{a}$ & $15.49 a$ & $12.27 a$ & $4.20 \mathrm{~b}$ & $1.30 \mathrm{a}$ & $1.20 \mathrm{c}$ \\
\hline 3 & $15.02 \mathrm{a}$ & $15.16 a$ & $13.71 \mathrm{a}$ & $11.58 \mathrm{a}$ & $1.62 a$ & $1.31 \mathrm{c}$ \\
\hline 4 & $15.20 \mathrm{a}$ & $15.14 a$ & $13.11 a$ & $12.11 \mathrm{a}$ & $1.40 \mathrm{a}$ & $1.31 \mathrm{c}$ \\
\hline 5 & $15.25 \mathrm{a}$ & $15.32 a$ & $13.00 \mathrm{a}$ & $5.64 b$ & $1.34 a$ & $1.29 \mathrm{c}$ \\
\hline 6 & $15.12 a$ & $15.08 \mathrm{a}$ & $13.56 a$ & $13.93 a$ & $1.43 a$ & $1.38 \mathrm{bc}$ \\
\hline 7 & $14.93 a$ & $14.98 \mathrm{a}$ & $14.04 a$ & $14.96 \mathrm{a}$ & $1.60 \mathrm{a}$ & $1.78 a$ \\
\hline LSD $(5 \%)$ & NS & NS & NS & $3.68^{\star \star}$ & NS & $0.233^{* \star}$ \\
\hline
\end{tabular}

** Significant at $p=0.01, \mathrm{NS}=$ non significant

Yield: With respect to the actual yield obtained, in 2001-2002 season there was no significant difference among the treatments applied on 'TA' (Table 3). In 2002-2003 season, however, a significantly lower yield was observed for treatments two, three and control trees than for the remaining treatments on 'TA'. According to an experiment conducted by Oosthuyse and Jacobs (1996) on 'Sensation', a reduction in fruit retention, number and tree yield was associated with pruning the terminal shoots $5 \mathrm{~cm}$ beneath the site of apical bud or inflorescence attachment as opposed to this site. Chang and Leon (1987) and Nakasone and Paull (1998), indicated that deblossoming of the terminal inflorescence could lead to inflorescence development from axillary buds, a 20-30 day later harvest and higher yields. The trend showed that, if the experiment would have been extended for other forthcoming seasons, trees that received treatments one, four, five and six could produce superior yield than the other treatments and the control. On ' $\mathrm{KT}$ ' trees, there was no significant difference among the treatments regarding the yield of the trees in both the seasons (Table 4). It should be noted that a good result is normally expected with a combination of pruning treatments than a single treatment based on cultivars and their growth habits.

Fruit quality parameters: After the shipping simulation storage, in both seasons, 'TA' fruit from treatment one were significantly softer than the other treatments (Table 5). The overall difference in the two seasons was not significant. On ' $\mathrm{KT}$ ' trees, there was no significant difference for firmness in the first season but in the second season, treatment one produced firm fruit (unlike in the case of 'TA') next to the control trees (Table 6). Ripening of many fruit is characterized by softening of the flesh and softening is thought to be brought about, amongst other factors, by the concerted action of different cell wall hydrolases, whose activity changes during ripening and alters the properties of many cell wall constituents, like pectin (Gomez-Lim, 1997). Softening during mango ripening is accomplished by solublization of pectin (Brinson et al., 1988). Significantly higher TSS values were observed in 'TA' from treatments four and five in both the seasons (Table 5). The TSS value for the control trees was lower than the other treatments in season two and only greater than treatment two in season one. For ' $\mathrm{KT}$ ' trees, there was no significant difference on total soluble solids on both seasons (Table 6). Like in the case of firmness, the season's difference was not significant. No clear relation between firmness and total soluble solids was observed. Lack of correlation between firmness and total soluble solids was also true for pruning treatments on 'Sensation' and the higher TSS value was obtained for October pruning together with fruit thinning (Fivas and Stassen, 1996). There seems to be a logical reason for the increase in TSS of fruit from renewal and post harvest pruning treatments. In the case of immediate post harvest pruning, the trees will get enough time to produce a new flush and those flushes mature early in the season especially for early cultivars. As compared to old flushes, new and matured leaves that are produced after pruning are able to manufacture more photsynthate and consequently a higher reserve. The implication with sufficient reserve and fruit number not exceeding the tree's capacity is that all the developing fruit would receive an adequate supply of carbohydrates. Regarding renewal pruning, by removing dead and dying plant parts (with reduced photosynthesis efficiency) as well as poorly developed and excess fruit, the plant reserve is conserved for the healthy developing fruit and improves the tree's fruit retention potential. Fivas et al. (1997) explained this phenomenon as bearers with weak, misshaped and small fruit are cut back by renewal pruning and on the remaining bearers the fruit are thinned to numbers the tree can cope with. Hence by practising renewal pruning, firstly it removes 'carbon starved, exhausted' fruiting shoots which will not fruit in next season and secondly, old leaves with reduced 
efficiency are replaced with young and active leaves that makes a better chance to build up carbohydrate reserves (even with winter photo inhibition) (Wolstenholme and Whiley, 1995). The effect of the treatments on the fruit's titratable acids content was found to be statistically non-significant for ' $\mathrm{TA}$ ' in both seasons (Table 5). During 2002-2003 season, treatments two and five produced significantly lower fruit titratable acids on ' $\mathrm{KT}$ ' trees (Table 6). A non-significant negative correlation ( $\mathrm{r}=-0.567, p=0.185)$ was observed between the amount of total soluble solids and that of titratable acids from 'TA' fruit analysis. Lakshminarayana (1980) explained that the titratable acids of fruit decrease during ripening. The predominant acid in common mango pulp is citric acid and the secondary acids are malic and tartaric acid in varying proportions depending on the cultivars and ripening stage. The reduction of acidity during ripening, plays a great part in the acid: sugar balance and, consequently, in influencing the taste and flavour of the fruit.

\section{Acknowledgement}

The authors would like to thank Bavaria Fruit Estate for using mango trees for conducting the trial and Mr. J. Fivas for valuable ideas on the technical aspects of the experiment. His team also helped a lot during data collection and harvesting.

\section{References}

Brinson, K., P.M. Dey, M.A. John and J.B. Pridham, 1988. Post harvest changes in Mangifera indica mesocarp cell walls and cytoplasmic polysaccharides. Phytochemistry, 27: 719-723.

Chadha, K.L. and R.N. Pal, 1986. Mangifera indica. In: Halevy, A.C. (ed.), CRC Handbook of Flowering, Vol. 5. CRC Press, Boca Raton, Florida, pp. 211-230.

Chang, M.T. and M.F. Leon, 1987. Delay fruit harvest by pinching mango inflorescence. Proceedings of the symposium on forcing culture of horticultural crops, held at Taichung: Taichung District Agricultural Improvement Station, special publication, p. 119128.

Chen, W.S. 1987. Endogenous growth substances in relation to shoot growth and flower bud development of mango. J. Amer. Soc. Hort. Sci., 112(2): 360-363.

Coetzer, L.A., S.A. Oosthuyse, D.L. Wishart and P.J. Robbertse, 1995. Influence of pruning on the flower sex ratio in some mango cultivars. S. Afr. Mango Growers' Assoc. Yearbook, 15: 27-30.

Davie, S.J., M. Van der Walt and P.J.C. Stassen, 1995. The energy demand of fruit production and its effect on fruit size in 'Sensation'. S. Afr. Mango Growers' Assoc. Yearbook, 15: 18-20.

Fivas, J. and P.J.C. Stassen, 1996. The effect of time of pruning and fruit thinning on yield and fruit quality of 'Sensation' mangoes. $S$. Afr. Mango Growers' Assoc. Yearbook, 16: 49-54.

Fivas, J., P.J.C. Stassen and H.G. Grove, 1997. Pruning and training strategies for Tommy Atkins and Sensation mango trees in higher density hedgerow systems. S. Afr. Mango Growers' Assoc. Yearbook, 17: 37-40.

GenStat for Windows. 2000. Release 4.2. Fifth Edition. Oxford: VSN International.
Gomez-Lim, M.A. 1997. Post harvest physiology, In: R.E. Litz (ed.) The Mango - Botany, Production and Uses. CAB International, Oxon. p. 425-445.

Issarakraisila, M., J.A. Considine and D.W. Turner, 1991. Pattern of vegetative and reproductive growth of mango trees in a warm temperature region of Western Australia. Acta Hortic., 291: 188-197.

Lakshminarayana, A.S. 1980. Mango. In: S. Nagy and P.E. Shaw (ed.) Tropical and Subtropical FruitsComposition, Properties and Uses. AVI Publishing Inc., Westport, Connecticut. p. 185-201.

Mullins, P.D.F. 1986. Effect of varying climatic regimes on flower behaviour and pollination in 'Sensation' and 'Haden' mango trees. S. Afr. Mango Growers' Assoc. Yearbook, 6: 3-42.

Nakasone, H.Y. and E.R. Paull, 1998. Tropical Fruits. CAB International, Oxon.

Nii, N., T. Watanbe, K. Yamaguchi and M. Nishimura, 1995. Changes of anatomical features, photosynthesis and ribulose bisphosphate carboxylase-oxygenase content of mango leaves. Ann. Bot., 76: 649-656.

Nunez-Elisea, R. and T.L. Davenport, 1995. Effect of leaf age, duration of cool temperature treatment, and photoperiod on bud dormancy release and floral initiation in mango. Sci. Hortic., 62(1-2): 63-73.

Oosthuyse, S.A. 1993. Research on Mango aimed at increasing orchard production and export fruit quality. S. Afr. Mango Growers' Assoc. Yearbook, 13: 40-44.

Oosthuyse, S.A. 1994. Pruning of sensation mango trees to maintain their size and effect uniform and later flowering. S. Afr. Mango Growers' Assoc. Yearbook, 14: 1-5.

Oosthuyse, S.A. 1995. Pruning of mango trees: an update. S. Afr. Mango Growers' Assoc. Yearbook, 15: 1-8.

Oosthuyse, S.A. and G. Jacobs, 1996. Flowering synchronization of 'Sensation' mango trees by winter pruning. Acta Hortic., 455(1): $422-430$.

Ram, S. 1993. Factors affecting mango tree architecture. Acta Hortic., 341: 177-191.

Reece, P.C., J.R. Furr and W.C. Cooper, 1946. The inhibiting effect of terminal bud on flower formation in the axillary buds of the 'Haden' mango. Amer. J. Bot., 33: 209-210.

Singh, R.N., P. K. Majumder, D.K. Sharma, G.C. Sinha and P. C. Bose, 1974. Effect of de-blossoming on the productivity of mango. Sci. Hortic., 2: 399-403.

Snedecor, G.W. and W.G. Cochran, 1980. Statistical methods (7th Ed.). Iowa State University Press.

Stassen, P.J.C., H.G. Grove and S.J. Davie, 1999. Tree shaping strategies for higher density mango orchards. J. Appl. Hort., 1(1): 1-4.

Stover, E.W. 1999. Relationship between intensity of flowering and cropping in fruits and nuts. ASHS 99 Workshop No. 6, Florida.

Suryanarayana, V. 1987. Seasonal changes in sugars, starch, nitrogen and $\mathrm{C}: \mathrm{N}$ ratio in relation to flowering in mango. Plant Biochem. J., 5: $108-117$.

Wolstenholme, B.N. and P.C. Mullins, 1982. Flowering, pollination and fruit set of mango -a discussion of limiting factors. S. Afr. Mango Growers' Assoc. Yearbook, 2: 5-11.

Wolstenholme, B.N. and A.W. Whiley, 1995. Ecophysiology of the mango tree as a basis for pre-harvest management. S. Afr. Mango Growers' Assoc. Yearbook, 15: 10-17. 